\title{
PENERAPAN FUNGSI MANAJEMEN DALAM MENINGKATKAN KEPUASAN ANGGOTA (Studi Kasus Di Koperasi Konsumen Syari'ah (KKS ) Barokah Tanjunganom)
}

\author{
Oleh \\ Baswarendra Guntur Hendratri \\ Institut Agama Islam Pangeran Diponegoro Nganjuk \\ baswarendraguntur@iaipdnganjuk.ac.id
}

\begin{abstract}
Abtsract
The financial institution's management process is the process of achieving an institution's or company's business based on the principles of management by utilizing the resources owned in accordance with the objectives to be achieved. The management process includes planning, organizing, directing and controlling. Implementation of a good management function will be a benchmark for the success of the KKS institution in providing services to its members. If the service provided is good, the member will feel satisfied.
\end{abstract}

Keywords: Management Functions, Member Satisfaction, Sharia Consumer Cooperatives

\begin{abstract}
Abstrak
Proses Manajemen lembaga keuangan merupakan proses pencapaian usaha suatu lembaga atau perusahaan yang berdasarkan prinsi-prinsip manajemen dengan memanfaatkan sumberdaya yang dimiliki sesuai dengan tujuan yang hendak dicapai. Proses manajemen meliputi perencanaan, pengorganisasian, Pengarahan dan pengendalian. Penerapan fungsi manajemen yang baik akan menjadi tolok ukur bagi keberhasilan lembaga KKS dalam memberikan pelayanan terhadap anggotanya. Apabila pelayanan yang diberikan baik maka anggota akan merasa puas.
\end{abstract}

Kata Kunci: Fungsi Manajemen, Kepuasan Anggota, Koperasi Konsumen Syariah 


\section{Pendahuluan}

Sistem perbankan syariah adalah sistem perbankan yang menerapkan prinsip bagi hasil yang saling menguntungkan bagi bank dan nasabah.Sistem perbankan syariah yang dalam pelaksanaannya berlandaskan pada syariah (hukum) Islam, menonjolkan aspek keadilan dan kejujuran dalam bertransaksi, investasi yang beretika, mengedepankan nilai-nilai kebersamaan dan persaudaraan dalam berproduksi dan menghindari kegiatan spekulatif dari berbagai transaksi keuangan. Lebih jauh lagi, kemanfaatannya akan dinikmati tidak hanya oleh umat Islam saja, tetapi dapat membawa kesejahteraan semua kalangan masyarakat (rahmatan lil alamin).

Perkembangan dunia perekonomian yang semakin pesat membuat semua industry ataupun lembaga juga ikut terpengaruh khususnya perbankan yang melayani penyediaan jasa dalam skala industry kecil, menengah sampai besar dengan peraturan pelayanan yang sama dalam hal pengelolaan dan pengalokasian dana masyarakat. Disisi lain juga terdapat lembaga yang menangani permasalahan keuangan untuk usaha kecil dan menengah dengan proses dan juga peraturan yang lebih sederhana dan tidak menyulitkan dalam penangananya, lembaga yang masih bernaung dengan dinas koperasi dan mengikuti semua peraturan dan ketentuan yang telah dibuat oleh dinas perkoperasian, dan mengikuti apa yang telah disepakati oleh para ulama dalam proses usaha yang halal dan semua peraturan dalam pelaksanaan usaha.

Koperasi Konsumen Syari'ah (KKS) atau sejenisnya dalam pelaksanaannya berlandaskan pada peraturan yang terdapat pada $\mathrm{Al}$ Qur'an, Hadist, ijma' dan qiyas yang dilakukan oleh para ulama mengenai system perekonomian saat ini yang semakin maju. Sebagai lembaga keuangan KKS harus dikelola secara professional, maka KKS harus menganut prinsip-prinsip manajemen. Oleh karena itu, KKS tidak boleh dikelola dengan asal-asalan. Setiap insan KKS haruslah mengikuti tren perkembangan lingkungan bisnisnya dengan melakukan inovasi-inovasi produk yang dilakukan dalam rangka merebut pasar. Tetapi juga tidak boleh menyalahi aturan atau ketentuan yang terdapat dalam syariat Islam tentang bermuamalah. 
Dalam pelaksanaanya KKS dilaksanakan berdasarkan prinsip kehatihatian dan tolong-menolong bebas dari unsur riba.

Proses dalam transaksi baik dari sebuah lembaga yang sangat besar seperti halnya perbankan maupun lembaga keuangan dalam skala kecil seperti koperasi atau KKS membutuhkan sebuah kepercayaan yang sangat besar dari masyarakat karena usaha ini merupakan usaha yang menawarkan sebuah jasa, jasa untuk mengelola dana nasabah yang diberikan maupun jasa dalam hal ini penyediaan modal atau dana bagi masyarakat yang membutuhkan modal. Oleh karena itu sebuah lembaga haruslah melayani anggota dengan sepenuh hati dan dengan menggunakan strategi yang sangat diperhitungkan dengan sebaik mungkin khususnya dalam hal perencanaan, pengorganisasian, pengarahan dan pengawasan dalam hal meningkatkan kepuasan anggota dan memperhatikan sebuah peraturan yang telah dibuat, seperti peraturan yang telah disepakati oleh dinas koperasi dan UKM (Usaha Kecil Menengah).

Pengelolaan dana masyarakat yang terdapat di KKS harus dikelola dengan sebaik mungkin, baik dalam penghimpunan maupun penyaluran dana masyarakat. Dalam pelaksanaanya KKS juga memiliki sistem yang sama dengan lembaga keuangan syariah, aktivitas usaha Bank atau Lembaga Keuangan lainya (KKS) dibagi menjadi dua, yaitu menghimpun dana dari masyarakat dalam bentuk simpanan, meliputi giro (wadi'ah), tabungan (wadi'ah dan murabahah) dan deposito (murabahah). Dan juga melakukan penyaluran dana melalui transaksi jual beli (murabahah, salam, ijarah dan istisna'), bagi hasil (mudharabah dan musyarakah),dan pembiayaan lainya (hiwalah, rahn, dan qard). ${ }^{1}$

Selain menjaga laporan keuangan di KKS dan menjaga laporan kolektabilitas agar tetap pada batas yang normal, pihak KKS juga menerapkan peraturan, sanksi, beserta dewan pengawas baik dari kantor capem sendiri maupun pengawas yang langsung dari pusat, untuk memantau seluruh kegiatan KKS baik kegiatan operasional

\footnotetext{
${ }^{1}$ Mohammad Ridwan, Manajemen Baitul Mal wa Tamwil, Yogyakarta: UII Press,2004, 150

${ }^{2}$ Lexi J Moleong, Metodologi Penelitian Kualitatif, Bandung, Volume 6 No.2 Juli 2019
} 
maupun kinerja karyawan di KKS itu sendiri. Selain setiap peraturan yang dibuat oleh KKS Barokah Tanjunganom sendiri dalam menjalankan kegiatan operasionalnya juga terdapat peraturan dari Menteri Koperasi dan Usaha kecil dan Menengah Republik Indonesia mengenai penilaian kesehatan koperasi Nomor : 14/Per/M.Kukm/XII/2009.

Dalam pengelolaan dana sebuah lembaga keuangan menggunakan rasio sebagai pengukuran untuk mempermudah dalam proses analisis dan mengevaluasi hasil kerja dan untuk menilai sebaik apa proses transaksi yang telah dijalankan dan sebagai bahan acuan untuk transaksi di bulan berikutnya. Usaha yang dilakukan oleh koperasi atau lembaga keuangan mikro harus layak artinya usaha tersebut harus dikelola secara benar dan efisien dan mampu menghasilkan keuntungan atau SHU (Sisa Hasil Usaha) dengan memerhatikan factor-faktor tenaga kerja, modal dan teknologi. Penerapan fungsi manajemen yang baik akan menjadi tolok ukur bagi keberhasilan KKS sehingga mampu meningkatkan antusias para anggota dalam menggunakan produk-produk yang ada. Selain itu dengan penerapan fungsi manajemen yang baik dan tepat yang diberikan oleh KKS Barokah Tanjunganom secara otomatis akan memberikan dampak positif yaitu peningkatan kepuasan anggotanya.

\section{Metode Penelitian}

Dalam Penelitian ini menggunakan pendekatan kualitatif yang memusatkan pada penerapan fungsi manajemen dalam meningkatkan kepuasan anggota. Menurut Lexi J. Moleong yang mendefinisikan penelitian kualitatif adalah prosedur penelitian yang menghasilkan data-data deskriptif berupa kata-kata tertulis atau lisan dari orangorang dan perilaku yang diamati. ${ }^{2}$ Sedangkan jenis penelitian ini adalah deskriptif kualitatif, yaitu penelitian yang dilakukan untuk meneliti status sekelompok manusia, suatu obyek, suatu kondisi, dan suatu sistem pemikiran ataupun suatu kelas peristiwa pada masa

${ }^{2}$ Lexi J Moleong, Metodologi Penelitian Kualitatif, Bandung, Remaja Rosda Karya, 2012, 2 
sekarang. Tujuan dalam penelitian ini adalah membuat deskripsi, gambaran atau lukisan secara sistematis, factual atau akurat mengenai fakta-fakta, sifat-sifat atau hubungan antaran fenomena yang diselidiki, yaitu tentang penerapan fungsi manajemen dalam meningkatkan kepuasan anggota.

Lokasi penelitian adalah Koperasi Konsumen Syari'ah Barokah di Jl. Ahmad Yani Gg. Duren No.02 Tanjunganom Nganjuk. Dalam penelitian kualitatif kehadiran peneliti sangat berpengaruh pada hasil penelitian sebab karakter penelitian kualitatif yang menggunakan studi lapangan. Sesuai dengan penelitian kualitatif, kehadiran peneliti di lapangan adalah sangat penting dan diperlukan secara optimal. Peneliti merupakan instrument kunci utama dalam mengungkapkan makna dan sekaligus merupakan sebagai alat pengumpul data. Oleh karena itu peneliti terlibat langsung dalam kehidupan orang-orang yang diteliti sampai pada tingkat keterbukaan antara kedua belah pihak. Peneliti hadir dan mengamati secara langsung penerapan fungsi manajemen dalam meningkatkan kepuasan anggota di KKS Barokah Tanjunganom, Kabupaten Nganjuk.

\section{Hasil Dan Pembahasan}

\section{Tentang KKS Barokah Tanjunganom Nganjuk}

KKS Barokah terletak di jalan Ahmad Yani Gg. Duren No.2 Tanjunganom Nganjuk jarak kantor KKS Barokah dari pusat kota Nganjuk \pm 16 KM. KKS Barokah pada awal berdirinya bernama KSU Barokah yang didirikan pada tahun 1998 dengan badan hukum no. 019/BH/KDK/13/IX/98. Kemudian pada awal tahun 2012 hasil dari Rapat Anggota Tahunan disepakati untuk membentuk unit usaha BMT (Baitul Maal Wattamwil atau Balai Usaha Mandiri Terpadu) atau unit Usaha Simpan Pinjam Pembiayaan Syari'ah (USPPS) yang pada awalnya unit usaha ini diberi nama BMT Barokah Amanah Syariah dan mulai berjalan pada tanggal 28 bulan April tahun 2012. Penamaan unit usaha Barokah Amanah Syariah mengandung filosofi karena pendiri menginginkan sebuah lembaga yang selain bisa mengemban amanah sebagai tempat untuk menyalurkan dana dari masyarakat kepada masyarakat lain yang membutuhkan secara syariah dan 
diharapkan juga kegiatan yang dijalankan mendapatkan keberkahan dari Allah SWT.

Tujuan dibentuknya unit usaha ini karena pendiri melihat banyak anggota koperasi dan masyarakat sekitar yang terjerumus pada praktek muamalah ribawi, rentenir dan perbankan konvensional yang memberatkan masyarakat dalam mengembangkan usahanya, khususnya pengusaha-pengusaha kecil, mereka merasa ekonominya tidak stabil dan banyak keluhan yang terjadi maka akhirnya muncullah gagasan dari pendiri untuk mendirikan unit usaha BMT atau USPPS ini, sebuah lembaga keuangan syariah yang benar-benar ingin menjalankan ekonomi secara syairah, dengan tekad dan semangat yang kuat untuk menolong masyarakat khususnya usaha-usaha kecil, sehingga dengan munculnya unit usaha simpan pinjam dan pembiayaan syariah ini masyarakat dapat terbantu.

Selanjutnya atas saran dari Dinas Perindustrian, Perdagangan, Koperasi, Pertambangan dan Energi (Disperindagkoptamben) Kabupaten Nganjuk, pengurus koperasi mengurus permohonan Perubahan Anggaran Dasar (PAD), untuk menambahkan unit BMT atau Unit Simpan Pinjam Pembiayaan Syariah ke dalam usaha koperasi. Akhirnya Pada tanggal 7 Februari 2014 KSU Barokah mendapatkan Akta Perubahan Anggaran Dasar dengan nomor 065/PAD/372.BH/426.101/2014 yang juga meresmikan perubahan bentuk koperasi dari KSU menjadi KJKS.

Namun, Selanjutnya setelah melalui berbagai workshop dan diklat yang diikuti oleh pengurus ataupun karyawan USPPS baik yang diadakan oleh Dinas Koperasi Propinsi Jawa Timur (Balatkop) di Malang maupun yang diadakan oleh pengurus Forum Komunitas Koperasi Syariah Jawa Timur (FKKS JATIM), serta saran dari berbagai pihak, dirasa lebih tepat apabila KJKS Barokah melakukan PAD lagi menjadi KKS (Koperasi Konsumen Syariah), karena bisa mengakomodir unit usaha selain USPPS yang lebih dahulu dijalankan oleh koperasi. Sebab KJKS dinilai lebih tepat digunakan oleh koperasi yang hanya memiliki USPPS saja, bukan untuk unit usaha retail. Sehingga pada tanggal 1 April 2016, KJKS Barokah resmi berubah 
menjadi KKS Barokah dengan Akta Perubahan Anggaran Dasar nomor 065/PAD/408.BH/426.101/2016.

KKS Barokah dalam memperoleh permodalannya berasal dari tiga sumber. Pertama, dari modal sendiri, yaitu modal yang berasal dari dana cadangan koperasi dan simpanan anggota (simpanan pokok dan simpanan wajib). Kedua, dari simpanan khusus anggota, yang diolah dalam produk simpanan mudharabah dan simpanan berjangka mudharabah. Ketiga, modal kerjasama pihak ketiga dan lembaga keuangan syari'ah.

Sedangkan dalam pengelolaannya, KKS Barokah membuat produk pembiayaan syariah, yaitu : Produk Pembiayaan Kerjasama Bagi Hasil (Pembiayaan Mudharabah), Produk Pembiayaan Jual Beli (Pembiayaan Murabahah), dan Produk Pembiayaan Jasa / Sewa (Ijarah).

\section{Pengertian dan Fungsi Manajemen}

Manajemen berasal dari bahasa latin yaitu dari kata manus yang berarti tangan dan agere yang berarti melakukan. Kata-kata itu digabung menjadi managere yang artinya menangani. Managere diterjemahkan ke Bahasa Inggris to manage (kata kerja), management (kata benda), manager untuk orang yang melakukannya, dan management diterjemahkan ke Bahasa Indonesia menjadi manajemen (pengelolaan). ${ }^{3}$

Menurut Malayu S.P Hasibuan, manajemen berasal dari kata to manage yang artinya mengatur. Apa yang diatur, apa tujuannya diatur, mengapa harus diatur, siapa yang mengatur, dan bagaimana mengaturnya. ${ }^{4} 1$. Yang diatur adalah semua unsur manajemen, yakni 6M. 2. Tujuannya diatur adalah agar $6 \mathrm{M}$ lebih berdaya guna dan berhasil guna dalammewujudkan tujuan. 3. Harus diatur supaya $6 \mathrm{M}$ itu bermanfaat optimal, terkoordinasi dan terintegrasi denganbaik dalam menunjang terwujudnya tujuan organisasi. 4. Yang mengatur

\footnotetext{
${ }^{3}$ Husaini Usman, Manajemen Teori, Praktik, dan Riset

Pendidikan,Jakarta:Bumi Aksara,2013, 06

${ }^{4}$ Hasibuan, Malayu S.P, Manajemen Sumber Daya Manusia., Edisi

Revisi. Jakarta: Penerbit PT Bumi Aksara,2012,6
} 
adalah pimpinan dengan kepemimpinannya yaitu pimpinan puncak, manajer madya, dan supervisi. 5. Mengaturnya adalah dengan melakukan kegiatan urut-urutan fungsi manajemen tersebut.

Manajemen merupakan suatu proses untuk mewujudkan tujuan yang diinginkan.Manajemen sebagai ilmu pengetahuan, manajemen juga bersifat universal danmempergunakan kerangka ilmu pengetahuan yang sistematis. Ilmu pengetahuan manajemendapat diterapkan dalam semua organisasi manusia, perusahaan, pemerintah, pendidikan, thsosial, keagamaan dan lain-lainnya.

Menurut Ricky W. Griffin manajemen merupakan sebuah proses perencanaan, pengorganisasian, kpengkoordinasian dan pengontrolan sumber daya untuk mencapai sasaran (goals) secara efektif dan efisien. Efektif berarti bahwa tujuan dapat dicapai sesuai dengan perencanaan, sementara efisien berarti bahwa tugas yang ada dilaksanakan dengan benar, terorganisir, dan sesuai jadwal. Manajemen merupakan ilmu social dan hanya merupakan alat untuk membantu tercapainya tujuan yang diinginkan, dan baru dapat diterapkan jika terdapat kerja sama antara dua orang atau lebih, tujuan yang ingin dicapai, pembagian kerja dan pembagian wewenang, pimpinan dan bawahan dan keterikatan formal diantara para anggota. Dalam sebuah lembaga, harus ada sebuah majanemen untuk mendukung setiap kegiatan yang dilakukan oleh lembaga. Fungsi manajemen dimulai dari perencanaan, pengorganisasian, pengarahan, dan pengendalian tentang seluruh kegiatan dari awal hingga akhir dengan menetapkan seluruh kegiatan yang harus dilakukan dan ancaman yang mungkin akan datang ketika proses kegiatan berlangsung serta merencanakan solusi untuk menangani ancaman yang mungkin bisa datang.

Fungsi manajemen adalah elemen-elemen dasar yang akan selalu ada dan melekat di dalam proses manajemen yang dijadikan acuan oleh manajer dalam melaksanakan kegiatan untuk mencapai tujuan. Fungsi manajemen pertama kali dikenalkan oleh seorang industrialis perancis bernama Henry Fayol pada awal abad 20. Saat itu dia menyebutkan bahwa terdapat lima fungsi manajemen, merancang, mengorganisir, memerintah, mengodinasi, dan mengendalikan. 
Namun saat ini kelima fungsi tersebut telah diringkas menjadi empat bagian yaitu:

1) Perencanaan (Planning)

Menurut Sutarno pada hakikatnya perencanaan merupakan proses pengambilan keputusan yang merupakan dasar bagi kegiatankegiatan atau tindakan-tindakan ekonomis dan efektif pada waktu yang akan datang. Proses ini memerlukan pemikiran tentang apa yang perlu dikerjakan, bagaimana dan dimana suatu kegiatan perlu dilakukan. ${ }^{5}$ Menurut Terry mengatakan, "Perencanaan merupakan pemilihan dan menghubungkan fakta, menggunakan asumsi-asumsi tentang masa depan dalam membuat visualisasi dan perumusan kegiatan yang diusulkan dan memang diperlukan untuk mencapai hasil yang diinginkan. ${ }^{6}$ Mengenai pentingnya suatu perencanaan, ada beberapa konsep yangtertuang dalam Al Qur'an dan Al Hadits. Di antara ayat Al Quran yang terkaitdengan fungsi perencanaan adalah Q.S Al-Hasyr ayatb $18^{7}$, yaitu :

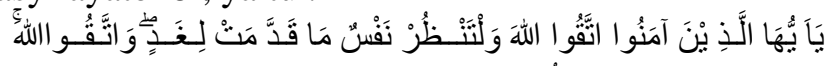

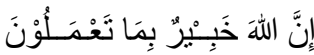

Hai orang-orang yang beriman, bertakwalah kepada Allah dan hendaklah setiap diri memperhatikan apa yang telah diperbuatnya untuk hari esok (akhirat); dan bertakwalah kepada Allah, sesungguhnya Allah Maha Mengetahui apa yang kamu kerjakan. (Q.S. Al Hasyr ayat 18).

Contoh lain dari perencanaan yang dilakukan Rasulullah Saw dapat ditemukan ketika terjadi perjanjian Hudaibiyyah (shulhul Hudaibiyyah). Dari perjanjian tersebut terkesan Rasulullah Saw kalah dalam berdiplomasi dan terpaksa menyetujui beberapa hal yang berpihak kepada kafir Quraisy. Kesan tersebut ternyata terbukti

${ }^{5}$ Sutarno,Serba-serbi Manajemen Bisnis,Yogyakarta,Graha Ilmu,2012,7

${ }^{6}$ Terry, George R, Prinsip-prinsip Manajemen,Bumi Aksara,2014,46

${ }^{7}$ Yayasan Penyelenggara Penerjemah/pentafsir Al-Qur'an Revisi

Terjemah oleh Lajnah Pentashih Mushaf Al-Qur'an Departemen Agama

Republik Indonesia Al-Qur'an dan Terjemah: Al-Jumanatul 'Ali(Seuntai Mutiara yang Maha Luhur), 2005, Bandung:CV J-ART, 919 
sebaliknya setelah perjanjian tersebut disepakati. Disinilah terlihat kelihaian Rasulullah Saw dan pandangan beliau yang jauh ke depan. Rasulullah Saw adalah insan yang selalu mengutamakan kebaikan yang kekal dibandingkan kebaikan yang hanya bersifat sementara. Walaupun perjanjian itu amat berat sebelah, Rasulullah Saw menerimanya karena memberikan manfaat di masa depan saat umat Islam berhasil membuka kota Mekkah (fath al Makkah) pada tahun ke-8 Hijriyah (dua tahun setelah perjanjian Hudaibiyah).

2) Pengorganisasian (Organizing)

Menurut Hasibuan Fungsi pengorganisasian (organizing=pembagian kerja) berkaitan erat dengan fungsi perencanaan, karena pengorganisasian pun harus direncanakan. Pengorganisasian adalah fungsi manajemen dan merupakan suatu proses yang dinamis. Pengorganisasian dapat diartikan penentuan pekerjaan-pekerjaan yang harus dilakukan, pengelompokan tugastugas dan membagi-bagikan pekerjaan kepada setiap karyawan, penetapan departemendepartemen (subsistem) serta penentuan hubungan-hubungan. Organizing berasal dari kata organize yang berarti menciptakan struktur dengan bagian-bagian yang diintegrasikan sedemikian rupa, sehingga hubungannya satu sama lain terikat oleh hubungan terhadap keseluruhannya. ${ }^{8}$

Organizing merupakan suatu kegiatan yang dilakukan dengan membagi suatu kegiatan besar menjadi kegiatan yang lebih kecil. Pengorganisasian mempermudah manager dalam melakukan pengawasan pada setiap pekerjaan yang ada, proses ini juga digunakan untuk menentukan orang yang dibutuhkan untuk melaksanakan tugastugas yang telah dibagi-bagi tersebut.pengorganisasian dapat dilakukan dengan cara menentukan tugas apa yang harus dikerjakan, siapa yang harus mengerjakan, bagaimana tugas tersebut dikelompokkan, siapa yang bertanggung jawab atas tugas tersebut, pada tingkat mana keputusan diambil.

${ }^{8}$ Hasibuan, Malayu S.P,Manajemen sumber Daya Manusia cet.2, Jakarta, PT Bumi Aksara,2012,118 
Menurut Silalahi untuk menghasilkan struktur organisasi yang efektif dan efisien, maka setiap pengorganisasian harus mengikuti sekuensi tahap-tahap dalam pengorganisasian sebagai berikut: ${ }^{9}$

a. Pembagian Kerja

Menurut Silalahi menetapkan pekerjaan-pekerjaan esensial untuk dikerjakan.Ini disebut pembagian kerja.Pembagian kerja adalah kegiatan mengurai pekerjaan dalam satuan-satuan tugas yang terspesialisasi sehingga tiap orang anggota organisasi mengerjakan dan bertanggung jawab melaksanakan seperangkat tugas yang terbatas, bukan keseluruhan tugas.

b. Departementalisasi

Menurut Silalahi departementalisasi adalah satu metode untuk membagi dan mengelompokkan pekerjaan ke dalam unit-unit organisasi yang terpisah yang bertanggung jawab untuk menyelesaikan tugas-tugas tertentu.

c. Distribusi Otoritas

Menurut Silalahi mendistribusi otoritas kepada unit-unit dan di antara individu-individu.Ini disebut distribusi otoritas atau pengelompokan otoritas.Kejelasan otoritas untuk tiap departemen atau unit organisasi dan orang penting untuk pelaksanaan tugas.

d. Koordinasi

Menurut Silalahi mengintegrasi semua orang, tugas-tugas dan aktivitas. Ini disebut koordinasi. Koordinasi adalah integrasi dari kegiatan-kegiatan individual dan unit-unit ke dalam satu usaha bersama yaitu bekerja ke arah tujuan bersama. Kebenaran yang tidak terorganisir dengan rapi akan dengan mudah bisa diluluhlantakkan oleh kebatilan yang tersusun rapi. Proses organizing yang menekankan pentingnya tercipta kesatuan dalam segala tindakan sehingga tercapai tujuan, sebenarnya telah dicontohkan di dalam $\mathrm{Al}$ Qurean. Firman Allah dalam surat Ali imran ayat $103^{10}$, yaitu : Dan

\section{${ }^{9}$ Silalahi, Ulber,Asas-asas Manajemen Bandung,PT Refika}

Aditama,2011,189

${ }^{10}$ Yayasan Penyelenggara Penerjemah/pentafsir Al-Qur'an Revisi Terjemah oleh Lajnah Pentashih Mushaf Al-Qur'an Departemen Agama 
berpeganglah kaтu semuanya kepada tali (agama) Allah, dan janganlah kamu bercerai berai, dan ingatlah akan nikmat Allah kepadamu ketika kamu dahulu (masa jahiliyah) bermusuh-musuhan, maka Allah mempersatukan hatimu, lalu menjadilah kamu karena nikmat Allah, orang-orang yang bersaudara; dan kamu telah berada di tepi jurang neraka, lalu Allah menyelamatkan kamu dari padanya. Demikianlah Allah menerangkan ayat-ayat-Nya kepadamu, agar kamu mendapat petunjuk (Q.S.Ali Imran ayat 103).

Selanjutnya al-Qur'an memberikan petunjuk agar dalam suatu wadah, tempat, persaudaraan, ikatan, organisasi, kelompok, janganlah timbul pertentangan, perselisihan, perscekcokan yang mengakibatkan hancurnya kesatuan, runtuhnya mekanisme kepemimpinan yang telah dibina. Firman Allah Q.S Al-Anfal ayat $46^{11}$, yaitu : Dan taatilah Allah dan RasulNya, jangalah kamu berbantah-bantahan yang menyebabkan kamu menjadi gentar, hilang kekuatanmu, dan bersabarlah, sesungguhnya Allah beserta orang-orang yang sabar (Al-Anfal : 46)

3) Pengarahan (Actuating)

Menurut Hasibuan fungsi pengarahan (actuating) adalah fungsi manajemen yang terpenting dan paling dominan dalam proses manajemen. Fungsi ini baru dapat dijalankan setelah rencana, organisasi dan karyawan ada. Pengarahan adalah mengarahkan semua karyawan agar mau bekerjasama dan bekerja selektif dalam mencapai tujuan perusahaan. ${ }^{12}$ Merupakan suatu tindakan untuk mengusahakan agar semua anggota kelompok berusaha untuk mencapai sasaran sesuai dengan perencanaan manajerial dan usaha. Pengarahan merupakan pekerjaan yang tidak mudah untuk dilakukan karena berkaitan langsung dengan manusia tersebut yang mempunyai pikiran, perasaan, harga diri dan kemauan.

Republik Indonesia Al-Qur'an dan Terjemah: Al-Jumanatul "Ali ( Seuntai Mutiara yang Maha Luhur ), 2005, Bandung: CV J-ART, 93

${ }^{11}$ Ibid, 268

${ }^{12}$ Hasibuan, Malayu S.P, Manajemen Sumber Daya Manusia cet.2, Jakarta, PT Bumi Aksara,2012,183 
Agar sebuah pengarahan dapat berjalan dengan lancar pemimpin harus lebih memerhatikan masalah-masalah "perilaku manusia, kepemimpinan, koomunikasi dan hubungan manusia". Dalam pemberian pengarahan, juga digunakan instruksi-instruksi yang menunjang pengetahuan mengenai aspek untuk melaksanakan suatu tugas tertentu.Untuk dapat melaksanakanya juga diberi data yang terperinci mengenai situasi, dan urutan langkah-langkah yang harus ditempuh. Instruksi-instruksi memang sulit dituliskan dan dapat menyita lebih banyak waktu namun akan semakin banyak. Al-Qur'an dalam hal ini sebenarnya telah memberikan pedoman dasar terhadap proses pembimbingan, pengarahan ataupun memberikan peringatan dalam bentuk actuating ini.

Suatu contoh pelaksanaan dari fungsi manajemen dapat ditemukan pada pribadi agung, Nabi Muhammad Saw. ketika ia memerintahkan sesuatu pekerjaan, beliau menjadikan dirinya sebagai model dan teladan bagi umatnya. Rasulullah Saw adalah al Qur"an yang hidup (the living Qur'an). Artinya, pada diri Rasulullah Saw tercermin semua ajaran Al-Qurean dalam bentuk nyata. Beliau adalah pelaksana pertama semua perintah Allah dan meninggalkan semua larangan-Nya. Oleh karena itu, para sahabat dimudahkan dalam mengamalkan ajaran Islam yaitu dengan meniru perilaku Rasulullah Saw.

4) Pengendalian (Controling)

Menurut Hasibuan fungsi pengendalian (controlling) adalah fungsi dari proses manajemen. ${ }^{13}$ Fungsi ini sangat penting dan sangat menentukan pelaksanaan proses manajemen. Fungsi ini sangat erat kaitannya dengan fungsi perencanaan dan kedua fungsi ini merupakan yang saling mengisi, karena pengendalian harus terlebih dahulu direncakan, pengendalian baru dapat dilakukan jika ada rencana kemudian tujuan baru dapat diketahui tercapai dengan baik atau tidak setelah pengendalian atau penilaian yang dilakukan. Controlling merupakan cara mengukur pelaksanaan dengan tujuan-tujuan

\footnotetext{
${ }^{13}$ Ibid. Hal 241
} 
menentukan sebab-sebab penyimpangan-penyimpangan dan mengambil tindakan-tindakan korektif dimana perlu.

\section{Kepuasan Pelanggan atau Konsumen}

Menurut Kotler dan Keller kepuasan adalah perasaan senang atau kecewa seseorang yang berasal dari perbandingan antara kesannya terhadap kinerja (atau hasil) suatu produk dan harapan harapannya. ${ }^{14}$ Sementara menurut Lovelock dan Wright kepuasan adalah keadaan emosional, reaksi pasca-pembelian mereka, dapat berupa kemarahan, ketidakpuasan, kejengkelan, netralitas, kegembiraan dan kesenangan. Kepuasan dipengaruhi oleh perbandingan layanan yang dipahami dengan pelayanan yang diharapkan, dan sebagai reaksi emosional jangka pendek pelanggan terhadap kinerja pelayanan tertentu. ${ }^{15}$ Indikator untuk mengukur kepuasan pelanggan, menurut Yuliarmi dan Riyasa adalah a) Kesesuaian kualitas pelayanan dengan tingkat harapan, b) Tingkat kepuasan apabila dibandingkan dengan yang sejenis, c) Tidak ada pengaduan atau komplain yang dilayangkan. ${ }^{16}$

Kepuasan adalah tingkat perasaan seseorang setelah membandingkan kinerja/ hasil yang dirasakannya dengan harapan. Kepuasan konsumen merupakan evaluasi purna beli dimana alternatif yang dipilih sekurang-kurangnya memberikan hasil (outcome) yang sama atau melampaui harapan konsumen, sedangkan ketidakpuasan timbul apabila hasil yang diperoleh tidak memenuhi harapan konsumen.Jadi tingkat kepuasan merupakan fungsi dari perbedaan antara kinerja yang dirasakan dengan harapan. Apabila kinerja

${ }^{14}$ Kotler, Philip \& Kevin L. Keller, Manajemen pemasaran jilid 1, edisi Ketiga belas, Terjemahan Bob Sabran,Jakarta:Erlangga,2009,Hlm 138

${ }^{15}$ Lovelock, Cristhoper \& Lauren Wright, Manajemen Pemasaran Jasa, Alih bahasa Agus Widyantoro (Cetakan Kedua),Jakarta:PT Indeks,2007,Hlm 102

${ }^{16}$ Yuliarmi, Ni Nyoman \& Putu Riyasa, Analisis faktor-faktor yang mempengaruhi kepuasan pelanggan terhadap pelayanan PDAM kota Denpasar ,2007, 12(1), 9-28. 
dibawah harapan, maka pelanggan akan kecewa dan tidak puas bila kinerja sesuai dengan harapan, pelanggan akan puas.

Sedangkan kinerja yang melebihi harapan, pelanggan akan sangat puas. Harapan pelanggan dapat dibentuk oleh pengalaman masa lampau, komentar dari kerabatnya serta janji dan informasi pemasar dan pesaingnya. Pelanggan yang puas akan setia lebih lama, mereka bersedia merekomendasi perusahaan, mau membayar sesuai mutu yang disampaikan, mengatakan hal-hal yang positif dari perusahaan, dan kurang sensitif terhadap harga. ${ }^{17}$

Sedangkan kepuasan pelanggan adalah keadaan yang dicapai bila produk sesuai dengan kebutuhan atau harapan konsumen dan bebas dari kekurangan.Kepuasan konsumen dapat didefinisikan pula sebagai suatu keadaan dimana, kebutuhan, keinginan, dan harapan pelanggan dapat terpenuhi melalui produk yang dikonsumsi. ${ }^{18}$ Memberikan nilai yang tinggi yaitu bertujuan untuk mendapatkan konsumen yang memilki tingkat kesetiaan terhadap merek, toko, atau perusahaan tertentu. ${ }^{19}$ Oliver mendifinisikan kesetiaan pelanggan sebagai "komitmen yang dipegang kuat untuk membeli lagi atau berlangganan lagi produk atau jasa tertentu di masa depan meskipun ada pengaruh situasi dan usaha pemasaran yang berpotensi menyebabkan peralihan perilaku."

Kunci untuk menghasilkan kesetiaan pelanggan yang tinggi adalah menyerahkan nilai pelanggan yang tinggi. Michael learning, dalam karyanya Delivering Profitable Value, mengatakan bahwa perusahaan harus merangsang satu proposi nilai unggul yang di arahkan pada segmen pasar khusus, dengan di dukung oleh system penyerahan nilai yang unggul. System penyerahan nilai mencangkup semua pengalaman yang di dapatkan pelanggan pada cara untuk mendapatkan dan menggunakan tawaran.

\footnotetext{
${ }^{17}$ Daryanto dan Ismanto Setyobudi, KONSUMEN dan Pelayanan, 37 ${ }^{18}$ Ibid, 90

${ }^{19}$ Philip Kotler,2007, Manajemen Pemasaran,Indonesia edisi 12: PT INDEKS,bab V,175
} 


\section{Kesimpulan}

Dari beberapa pembahasan di atas dapat dianalisis data sebagai berikut: KKS BarokahTanjunganom telah melakukan proses perencanaan dalam mengelola koperasi yang terdiri dari perencanaan jangka panjang dan perencanaan jangka pendek. Hal ini seharusnya menjadikan koperasi konsumen syari'ah tidak mungkin lagi salah arah dalam menentukan pekerjaan organisasi dan telah memiliki arah tujuan yang jelas dalam mencapai target organisasi.

Kaitannya dengan kepuasan anggota menunjukkan bahwa perencanaan jangka panjang dan jangka pendek yang ditulis dalam bentuk renstra tersebutmemberikan gambaran yang jelas dan lengkap tentang seluruh pekerjaan, namun banyak anggota menyatakan kurang tahu dengan adanya renstra tersebut. Hal ini menunjukkan bahwa perencanaan yang sifatnya sebagai tolok ukur keberhasilan organisasi kurang di dalam hal mensosialisasikannya kepada para anggota.Keadaan ini mengakibatkan banyak anggota kurang berperan aktif dalam memajukan koperasi,dikarenakan tidak memahami tujuan atau target yang ingin dicapai oleh koperasi dalam masa panjang.

Lembaga KKS Barokah juga telah melakukan proses pengorganisasian dalam memanejemen lembaga melalui adanya struktur organisasi yang menjelaskan garis koordinasi dan tanggung jawab, serta diikuti pula dengan menjelaskan tugas masing-masing bidang kedalam tupoksi masing-masing. Keadaan ini seharusnya mengarahkan aktifitas para pengurus yang terarah dan tidak merangkap dalam penyelesaian pekerjaan yang sama. Namum demikian Keadaan inilah yang menjadikan pekerjaan yang tumpang tindih, banyak pelayanan yang diharapkan anggota selesai terlambat dan cenderung lama, karena masing-masing pengurus masih menyelesaikan pekerjaan yang lain. Disamping itu belum adanya karyawan yang memiliki kriteria dan kompetensi yang diharapkan oleh lembaga sehingga menyebabkan adanya perangkapan tugas. 


\section{Daftar Pustaka}

Al-Qur'an Terjemah Kementerian Agama Republik Indonesia, 2005

Andika Sanjaya, Uji Keabsahan Data pada Penelitian Kualitatif, 2018

Asiyah Binti Nur, Manajemen Pembiayaan Bank Syari'ah, Yogyakarta, 2014

Arikunto, Suharsini: Prosedur Penelitian Suatu Pendekatan Praktik, Rineka Cipta, Jakarta, 2013.

Awar Saifudin, Metode Penelitian, Yogyakarta, Pustaka Pelajar Offset, 2012

Choliq Abdul, Pengantar Manajemen, Semarang, 2011

Daryanto dan Ismanto Setyobudi, Konsumen dan Pelayanan

Hasibuan Malayu S.P, Manajemen Sumber Daya Manusia, Jakarta,2016

J Moleong, Lexi: Metodologi Penelitian Kualitatif, Remaja Rosda Karya, Bandung, 2012

Kolter Philip \& Kevin L Keller, Manajemen Pemasaran, 2009

Lovelock, Crsthoper \& Lauren Wright, Manajemen Pemasaran Jasa, 2007

Usman Husaini, Manajemen Teori Praktek dan Riset Pendidikan, Jakarta, 2013

Satori, Djam'an dan Aan Komariyah, Metodologi Penelitian kualitatif: Bandung Alfabeta, 2012

Siagian, Manajemen Suatu Pengantar, Bandung, 2012

Silalahi Ulber, Asas-asas Manajemen, Bandung, 2011

Sugiyono, Metode Penelitian Kualitatif, Bandung, 2012

Sutarno, Serba-serbi Manajemen Bisnis, Yogyakarta, 2012

Terry George R, Prinsip-prinsip Manajemen,2014

Ranupandojo Heidirachman, Dasar-dasar Manajemen, Yogyakarta, 2012

Ridwan Mohammad, Manajemen Baitul Mal wa Tamwil, Yogyakarta, 2004

Yuliarmi Ni Nyoman \& Putu Riyasa, Analisis Faktor-faktor yang Mempengaruhi Kepuasan Pelanggan, Denpasar, 2007 